\title{
Sustainable Biobutanol and Working towards the Green Gasoline of the Future
}

\section{Yaser Dahman*}

Department of Chemical Engineering, Ryerson University, Toronto, M5B 2K3 Ontario Canada

With world energy consumption predicted to increase 54\% between 2001 and 2025, primary attention has been directed towards the development of carbon neutral energy and sustainable sources to meet the future needs [1]. Reductions of fossil fuels, environmental deterioration, and fluctuating prices of traditional fuels have revived an interest in the development of renewable fuels. Concerns regarding green house gas emission, energy scarcity and the desire for energy independence are increasing the pace and intensity of biofuel research and commercialization. Biofuels are an attractive substitute to current petroleum based fuels because they can be utilized as transportation fuels with diminutive change to current technologies; they also have significant potential to improve sustainability and reduce greenhouse gas emissions. Liquid (i.e., ethanol, butanol, biodiesel) or gaseous (i.e., methane or hydrogen) biofuels are generally produced from organic materials such as starch, oilseeds and animal fats or cellulose and agricultural biomass. While in some countries such as South Africa and Russia, ABE fermentation process remained competitive due to the low raw material and labor costs, it had lost competitiveness in other countries by 1960 s, owing to the increase of feedstock costs and advancement of the petrochemical industry [2]. Since the late 1990s global biofuel research has steadily been on the rise, with new modified micro-organisms, pretreatments, process configurations and technologies, thereby improving conversion efficiencies and decreasing production cost. In first-generation biofuel, plant sugars and starch from food crops were fermented to biofuel by yeast. The advent of second-generation biofuels broadened the feedstock base to include non-food cellulosic biomass by incorporating chemical or enzymatic hydrolysis in various process configurations [3]. Third-generation biofuels employed enzyme-producing micro-organisms such as algae, to hydrolyze plant polymers and ferment the resulting sugars. The Canadian government supports the development of biofuel production through a $\$ 2$ billion commitment in the 2007 Federal Budget. A longstanding federal and provincial excise tax exemption on renewable fuels has encouraged the renewable fuels to be competitive with gasoline. In the United States, according to a report from the Department of Energy (DOE) titled "Roadmap for Biomass Technology in the United States", bio-based transportation fuels are projected to increase from $0.5 \%$ of U.S consumption in 2001 to $4 \%$ in $2010,10 \%$ in 2020 , and further to $20-30 \%$ in 2030 , or about 60 billion gallons of gasoline equivalent per year. This is in addition to 10-12 billion pounds of butanol annually required for industrial energy consumption [4].

Although there was more focus on fermentation of ethanol due to its vast applications in industry, more interest has recently intensified on butanol for its similar characteristics to gasoline, which allow the direct use of butanol in any gasoline engine without modification and/or substitution [5]. More importantly, butanol can be mixed with gasoline in any proportion [6,7]. Interestingly, while the current automotive engine cannot tolerate more than $15 \%$ ethanol, n-butanol can be used up to $100 \%$ in unmodified 4-cycle ignition engines or blended up to $30 \%$ ( $70 \%$ diesel) in a diesel compression engine or to
$20 \%$ (80\% kerosene) in a jet turbine engine [8,9]; Butanol, a product of acetone-butanol-ethanol (ABE) fermentation, is an excellent feedstock chemical in the plastics industry, a food-grade extract in the food and flavor industry and more importantly, a superior fuel to ethanol $[10,11]$. Biobutanol is a biofuel that can be produced from renewable resources using special strains of bacteria such as Clostridium acetobutylicum or Clostridium beijerinckii [12]. The advantage of using these strains is that they can utilize both lignocellulosic hydrolysate sugars (hexoses and pentoses) in contrast to traditional ethanolproducing yeast strains that cannot do that [13]. As a biofuel, butanol has some interesting properties that other fermentation derived fuels do not have $[14,15]$. Butanol contains $22 \%$ oxygen which makes it an excellent fuel extender. It is more hydrophobic than ethanol and mixes better with hydrocarbon fuels. It is not sensitive to water, less volatile, less hazardous to handle, and less flammable than ethanol [16,17]. The lower vapor pressure makes it suitable for use as an oxygenator. Its adaptability and integration into the current transportation technology can revolutionize energy consumption and will contribute to climate change mitigation without having detrimental side effects on the environment. Moreover, using agricultural biomass as a renewable feedstock for biobutanol production improves food security, land use, and environmental protection Table 1.

Considering all recent technologies in microbial physiology, strain development, fermentation and low-energy fuel separation, biobutanol is the new generation of green biofuel that is cost-effective, burns clean, and enhances environmental sustainability. Whether it will be used as a standalone transportation fuel, an additive to gasoline or diesel fuel, or an additive to improve the properties of ethanol, biobutanol technologies offer a more sustainable and environmentally friendly future.

\begin{tabular}{|l|c|c|c|c|}
\hline Fuel Property & Gasoline & Butanol & Ethanol & Methanol \\
\hline Energy density (MJ/L) & 32.00 & 29.20 & 19.60 & 16.00 \\
\hline Air-Fuel ratio & 14.60 & 11.20 & 9.00 & 6.50 \\
\hline Specific energy (MJ/kg air) & 2.90 & 3.20 & 3.00 & 3.10 \\
\hline Heat of vaporization (MJ/kg) & 0.36 & 0.43 & 0.92 & 1.20 \\
\hline Research Octane Number (RON) & $91-99$ & $96-105$ & 129 & 136 \\
\hline Motor Octane Number (MON) & $81-89$ & $78-89$ & 102 & 104 \\
\hline
\end{tabular}

Table 1: Properties of common fuels with respect to gasoline [19]

*Corresponding author: Yaser Daman, Department of Chemical Engineering, Ryerson University, Toronto, M5B 2K3 Ontario Canada, Tel: 1 416-979-5000 ext. 4080; Fax: 1416-979-5083; E-mail: ydahn@ryerson.ca

Received April 27, 2012; Accepted April 28, 2012; Published April 30, 2012

Citation: Dahman Y (2012) Sustainable Biobutanol and Working towards the Green Gasoline of the Future. Ferment Technol 1:e111. doi:10.4172/2167 7972.1000e111

Copyright: (c) 2012 Dahman Y. This is an open-access article distributed under the terms of the Creative Commons Attribution License, which permits unrestricted use, distribution, and reproduction in any medium, provided the original author and source are credited. 


\section{References}

1. EIA (1998) Annual energy outlook 1999, with projections to 2020, in DOE/EIA0383, Energy Information Administration, Department of Energy, Washington DC, USA.

2. Dragan Nimcevic, Richard Gapes J (2000) The Acetone-Butanol fermentation in pilot plant and pre-industrial scale. J Mol Microbiol Biotechnol 2: 15-20.

3. Olive D (2008) Conceived rush to ethanol: price of corn doubles in three years as more of crop is diverted to satisfy questionable biofuels policy. The Toronto Star

4. Donaldson GK, Huang LL, Maggio-Hall LA, Nagarajan V, Nakamura CE, et al. (2007) Fermentative production of four carbon alcohols

5. Qureshi N, Saha BC, Cotta MA (2007) Butanol production from wheat straw hydrolysate using Clostridium beijerinckii. Bioprocess Biosyst Eng 30: 419-427.

6. D'Aquino R (2007) Cellulosic ethanol - Tomorrow's sustainable energy source. Chem Eng Prog 3: 8-10.

7. Anon (2006) The next big thing: biobutanol. Fuels \& Lubes International. Quarter 3:19-22.

8. Schwarz WH, Gapes JR (2006) Butanol-rediscovering a renewable fuel BioWorld Europe 16-19.

9. Antoni D, Zverlov, Schwarz W (2007) Biofuel from microbes. Appl Microbio Biotechnol 77: 23-35

10. Formanek J, Mackie R, Blaschek HP (1997) Enhanced butanol production by
Clostridium beijerinckii BA101 grown in semidefined P2 medium containing 6 percent maltodextrin or glucose. Appl Environ Microbiol 63: 2306-2310.

11. Parekh M, Formanek J, Blaschek HP (1998) Development of cost-effective glucose-corn steep medium for the production of butanol by Clostridium beijerinckii. J Ind Microbiol Biotechnol 21:187-191.

12. Qureshi N, Saha BC, Cotta MA (2007) Butanol production from wheat straw hydrolysate using Clostridium beijerinckii. Bioprocess Biosyst Eng 30: 419-427

13. Qureshi N, Blaschek HP (2005) Butanol production from agricultural biomass In: Shetty K, Paliyath G, Pometto A, Levin RE (eds), Food biotechnology (2ndedn) New York: Taylor \& Francis.

14. Ezeji TC, Qureshi N, Blaschek HP (2003) Production of butanol by Clostridium beijerinckii BA101 and in-situ recovery by gas stripping. J Microbiol Biotechno 19: $595-603$

15. Annous B, Blaschek HP (1991) Isolation and characterization of Clostridium acetobutylicum mutants with enhanced amylolytic activity. Appl Environ Microbiol 57: 2544-2548.

16. Zverlov VV, Berezina O, Velikodvorskaya GA, Schwarz WH (2006) Bacteria acetone butanol production by industrial fermentation in Soviet Union: use of hydrolyzed agricultural waste from biorefining. Appl Microbiol Biotechnol 71: 587-597

17. Hector RE, Qureshi N, Hughes SR, Cotta MA (2007) Engineering Saccharomyces cerevisiae for ethanol production from agricultural waste products. Yeast Cell Biology 176. 